\title{
Deteksi Citra Pornografi Memanfaatkan Deep Convolutional Neural Network
}

\author{
Kevin Setiono, Teknologi Informasi Institut Sains dan Teknologi Terpadu Surabaya(ISTTS), \\ Yosi Kristian, Teknologi Informasi Institut Sains dan Teknologi Terpadu Surabaya(ISTTS), \\ Gunawan, Teknologi Informasi Institut Sains dan Teknologi Terpadu Surabaya(ISTTS).
}

\begin{abstract}
Abstrak-Internet merupakan salah satu sumber informasi yang sangat mudah diakses dan sangat lengkap pada zaman sekarang ini. Dari banyaknya konten tersebut terdapat konten pornografi yang meresahkan dan memberikan dampak buruk pada perkembangan anak-anak. Hingga tahun 2020 pemblokiran konten pornografi menyumbang 70 persen dibandingkan konten negative lainnya. Metode untuk mencegah/memblokir konten pornografi ada berbagai macam mulai dari memblokir websitenya hingga mendeteksi berdasarkan citra yang ada. Penelitian ini akan mencoba mendeteksi citra pornografi dengan bantuan Deep Convolutional Neural Network. Pembuatan model menggunakan transfer learning hingga fine tuned fine transfer learning dan mencoba model-model state of the art. Penelitian ini menghasilkan model yang mampu mendeteksi citra pornografi dengan akurasi $\mathbf{7 8 \%}$. Selain memiliki akurasi yang cukup tinggi model ini juga mampu mendeteksi bagian-bagian intim dari wanita yang menjadi fitur dari citra pornografi. Kemampuan mendeteksi fitur tersebut telah diujicoba dengan mengubah model yang digunakan penelitian ini sebagai detektor objek pada citra pornografi.
\end{abstract}

Kata Kunci-Convolutional Neural Network, Deteksi Citra Pornografi, Deep Learning, EfficientNet.

\section{PENDAHUluan}

$\mathrm{K}$ onten yang ada pada Internet saat ini sangatlah banyak dan lengkap. Banyaknya konten tersebut tidak dapat menjamin seluruh konten yang ada selalu konten positif. Konten pornografi merupakan konten negatif yang tersebar dengan luas dan dengan mudah ditemukan di Internet. Korban dari konten negatif internet dimulai dari anak di usia muda (11 hingga 13) tahun[1]. Dikarenakan permasalahan diatas masalah untuk melakukan deteksi pornografi menjadi salah satu hal yang penting dilakukan dalam penelitian Computer Vision maupun dalam bidang Machine Learning. Penelitian ini akan membahas lebih detail mengenai metode untuk melakukan deteksi dengan bantuan Machine Learning.

Di Indonesia yang memiliki jumlah penduduk lebih dari 264 juta jiwa, terdapat 171 juta jiwa yang menggunakan

Kevin Setiono, Departemen Teknologi Informasi, Institut Sains dan Teknologi Terpadu Surabaya, Surabaya, Jawa Timur, Indonesia (e-mail: kevinsetiono@stts.edu)

Yosi Kristian, Departemen Teknologi Informasi, Institut Sains dan Teknologi Terpadu Surabaya, Surabaya, Jawa Timur, Indonesia (e-mail: yosi@stts.edu)

Gunawan, Departemen Teknologi Informasi, Institut Sains dan Teknologi Terpadu Surabaya, Surabaya, Jawa Timur, Indonesia (e-mail: gunawan@stts.edu)
Internet. Selama pertengahan tahun 2018 hingga awal tahun 2019 Kementrian Komunikasi dan Infromatika telah melakukan pemblokiran situs dengan konten negatif. Hasilnya sebanyak 898.108 konten pornografi ditemukan dan berhasil di blok[2]. Jumlah konten pornografi ini merupakan konten yang terbanyak dari seluruh konten negatif yang ditemukan. Konten negatif tersebut meliputi Citra Pornografi, Hoaks, Fraud, penipuan online, radikalisme, perjudian, dan lain-lain. Pada penelitian ini fokus akan diarahkan pada deteksi citra pornografi.

Pornhub merupakan salah satu situs penyedia pornografi terbesar yang ada. Pornhub mengeluarkan ulasan sepanjang tahun 2019 pada blog Pornhub Insights[3]. Berdasarkan pencarian 5 kata kunci yang paling sering dicari oleh user adalah Japanese, Hentai, Lesbian, MILF, dan Korean. Sedangkan perbandingan jumlah penonton Pria mendominasi dengan angka $68 \%$ dibandingkan Wanita yang hanya $32 \%$ saja. Penonton Wanita banyak menonton genre Lesbian pada situs Pornhub.

Computer Vision dapat memfilter konten pornografi dengan mengambil citra yang tampil pada sebuah website dan mengolahnya. Deteksi dengan menggunakan Computer Vision sendiri secara umum dapat dibagi ke dalam dua bagian yaitu dengan menggunakan Neural Network dan tanpa menggunakan Neural Network/Machine Learning. Selain untuk mendeteksi citra pornografi Deep Convolutional Neural Network (DCNN) juga telah digunakan untuk mengklasifikasi textur serat kayu pada citra mikroskopik[4] dan mengklasifikasi post Kesehatan[5].

Penelitian deteksi citra pornografi telah dilakukan sejak cukup lama. Metode yang digunakan untuk deteksi pornografi juga bermacam-macam. Cara yang umum digunakan pada Indonesia ialah dengan melakukan filter pada tautan yang akan diakses oleh pengguna[6]. Hal ini membuat pengguna tidak dapat mengakses website-website yang mengandung konten pornografi.

Banyak metode dilakukan oleh peneliti yaitu dengan menggunakan penelitian berbasis warna. Warna dapat dijadikan salah satu metode untuk mendeteksi pornografi karena pada citra pornografi banyak menampilkan bagian yang menjukkan warna kulit[7]. Metode ini dilakukan oleh beberapa peneliti terdahulu. Cara lain yang dilakukan untuk mendeteksi dengan menggunakan color histogram[8]. Perkembangan lain dengan menggunakan basis warna 


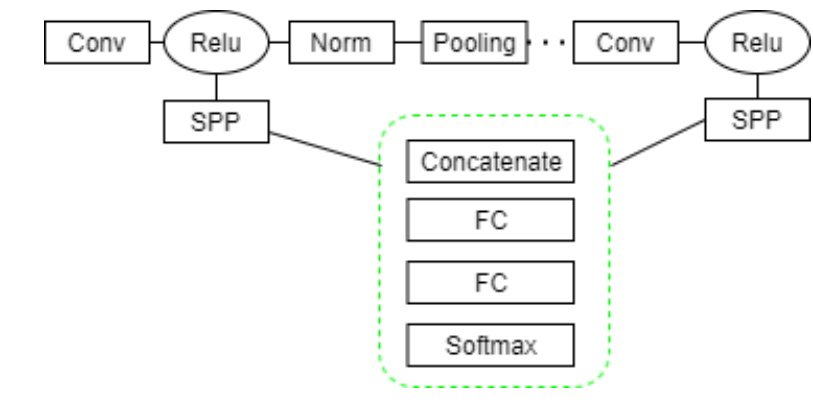

Gambar. 1. Multi Level Feature Framework

adalah dengan menggabungkan deteksi wajah dengan deteksi warna kulit dikarenakan area pornografi pada tubuh memiliki karakteristik yang hampir sama dengan wajah[9].

Metode yang digunakan untuk mendeteksi citra pornografi juga mengalami pergeseran seiring perkembangan dari computer vision dan machine learning. Wang[10] melakukan deteksi pornografi dengan menggunakan CNN dengan sifat strongly supervised. $\mathrm{Li}[11]$ melakukan penelitian dengan memanfaatkan CNN untuk mendapatkan fitur dari citra kemudian mengolah hasil tersebut menjadi detektor pornografi. Ganguly[12] menggunakan CaffeNet untuk deteksi citra dengan intensi pornografi.

Kontribusi yang diberikan oleh penulis melalui penelitian ini adalah sebagai berikut :

- Membuat dataset untuk citra pornografi

- Membuat model yang mampu mendeteksi citra pornografi dengan akurasi tinggi dan resource seminimal mungkin

- Merancang pipeline untuk mendeteksi citra pornografi

\section{PENELITIAN TERKAIT}

Citra pornografi harus didefinisikan untuk mempermudah dalam penentuan citra yang tergolong pornografi dan mana yang tidak. Definisi citra pornografi diambil dari penelitian milik Wang[10], dimana pada sebuah citra pornografi adalah citra yang menampilkan salah satu organ intim secara eksplisit. Definisi ini membantu penentuan dalam pembuatan dataset citra pornografi pada penelitian ini.

Kemampuan dari Deep Convolutional Neural Network untuk mendeteksi fitur dari citra pornografi juga sebelumnya telah dicoba pada penelitian Li. Li[13] membuat CNN untuk mengekstrak fitur pornografi pada setiap layernya, kemudian fitur tersebut digunakan untuk menentukan sebuah citra merupakan pornografi atau tidak. Gambaran dari sistem yang dibuatnya dapat dilihat pada Gambar 1 .

Dewantoro[14] membuat penelitian untuk mendeteksi puting pada payudara Wanita. Pada penelitian ini dia membuat pemeriksaan dalam beberapa tahapan, tahapan tersebut dilakukan karena ada kesamaan antara bagian tubuh manusia dengan wajah. Pada penelitian ini akan menggunakan juga kerangka tahapan yang digunakan dewantoro sebagai dasar dalam pembuatan hierarki dalam mendeteksi citra pornografi.

Perkembangan dari CNN mengalami kemajuan sangat pesat dimulai dari munculnya Alex-Net yang memiliki jumlah hidden layer lebih banyak. Semenjak ini mulailah perkembangan $\mathrm{CNN}$ yang semakin dalam hingga disebut

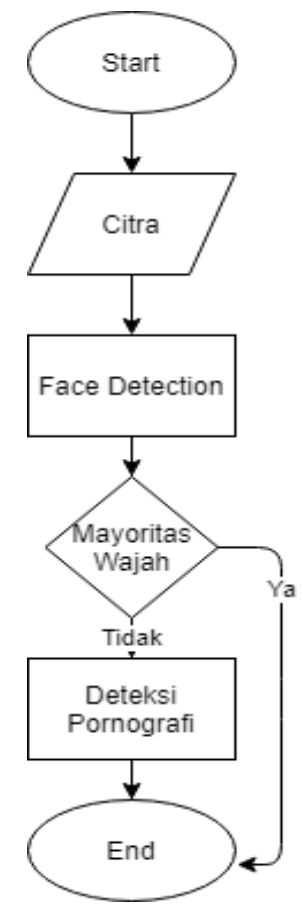

Gambar. 2. Sistem Deteksi Pornografi

Deep Convolutional Neural Network. Model-model yang akan dicoba diantaranya VGG16[15], ResNet[16], MobileNetV2[17] dan EfficientNet[18].

Beberapa model yang dicoba juga merupakan model yang state of the art, yaitu model yang memiliki hasil akurasi yang tinggi namun menggunakan jumlah resource yang kecil. Model ini adalah MobileNetV2 dan EfficientNet. Model yang diusulkan akan dibuat dengan menggunakan dasar dari model-model ini.

Selain menjadikan model ternama sebagai dasar pembuatan model, model-model ini juga akan dicoba dengan menggunakan metode transfer learning. Selain dengan menggunakan transfer learning akan dicoba juga dengan menggunakan salah satu metode transfer learning yaitu Fine Tuning. Fine tuning adalah salah satu metode yang sangat baik untuk membuat sebuah klasifier dari citra dari model yang telah ada dengan menggunakan dataset buatan sendiri.

\section{SISTEM YANG DIAJUKAN}

Penelitian ini mengusulkan pipeline sistem deteksi citra pornografi yang dapat dilihat pada Gambar 2. Pada pipeline ini dibuat beberapa tahapan untuk melakukan deteksi citra pornografi. Awalnya sebuah citra harus melalui proses deteksi wajah, penjelasan pentingnya deteksi wajah akan dijelaskan pada bagian III.A. Selanjutnya citra tersebut akan dideteksi dengan sistem cerdas berbasis Deep Convolutional Neural Network.

\section{A. Face Detection}

Citra pornografi memiliki karakteristik yang mirip dengan wajah. Hal ini sisi gelap terang dari citra pornografi hampir sama dengan wajah (terang, gelap dan terang). Untuk mengurangi kemungkinan wajah dideteksi pornografi maka pada sistem yang akan dirancang ini akan melakukan deteksi wajah setelah menerima inputran citra. Deteksi citra 


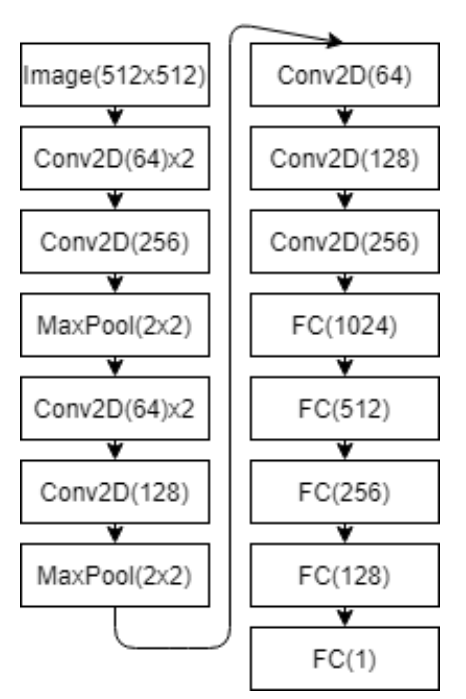

Gambar. 3. DCNN Pertama yang Diusulkan

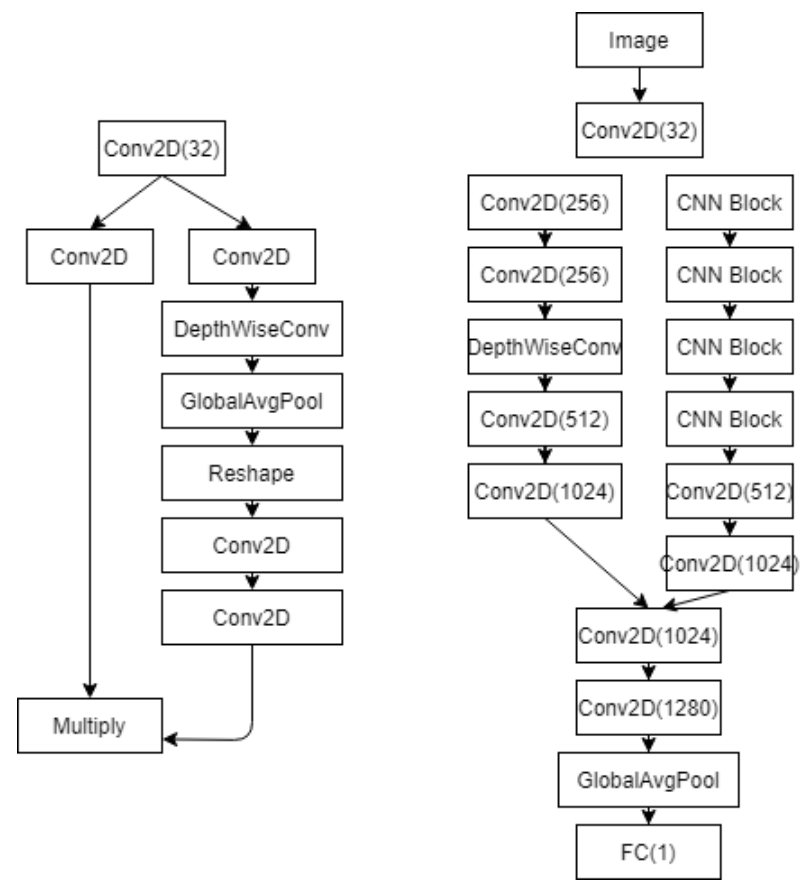

Gambar. 4. DCNN Kedua yang Diusulkan

wajah akan menggunakan Haarcascade. Citra yang memiliki proporsi sedikit maka akan dilanjutkan melalui proses deteksi pornografi.

\section{B. Deteksi Pornografi}

Bagian ini merupakan bagian yang akan menggunakan Deep Convolutional Neural Network. Deep Convolutional Network yang akan diuji coba meliputi Deep Convolutional Neural Network yang dibuat sendiri dan percobaan menggunakan CNN yang telah teruji. CNN yang akan dicoba tersebut adalah VGG16, ResNet-50, MobileNetV2, dan EfficientNet.

\section{DCNN Usulan}

DCNN buatan sendiri yang akan dicoba terdapat 2 macam : dibuat berbasis LeNet dan dibuat dengan menggunakan Residual Network. Detail dari DCNN pertama yang diusulkan dapat dilihat pada Gambar 2. Setiap blok pada

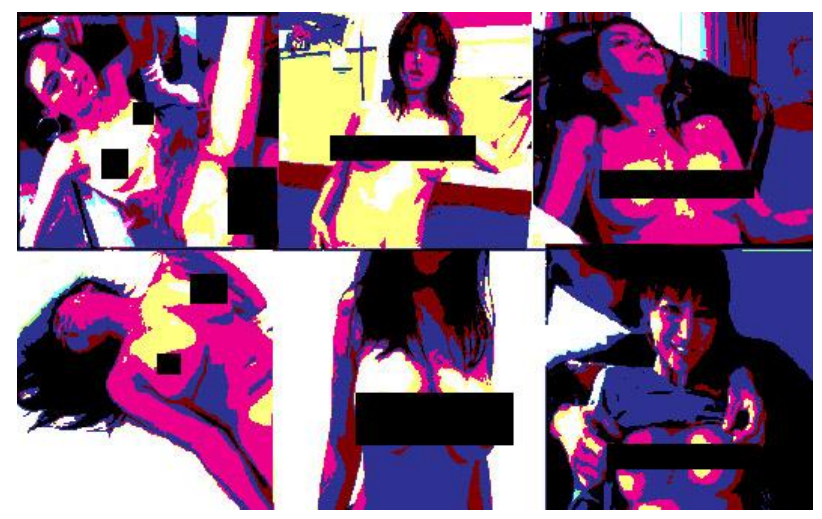

Gambar. 5. Citra Pornografi pada Dataset

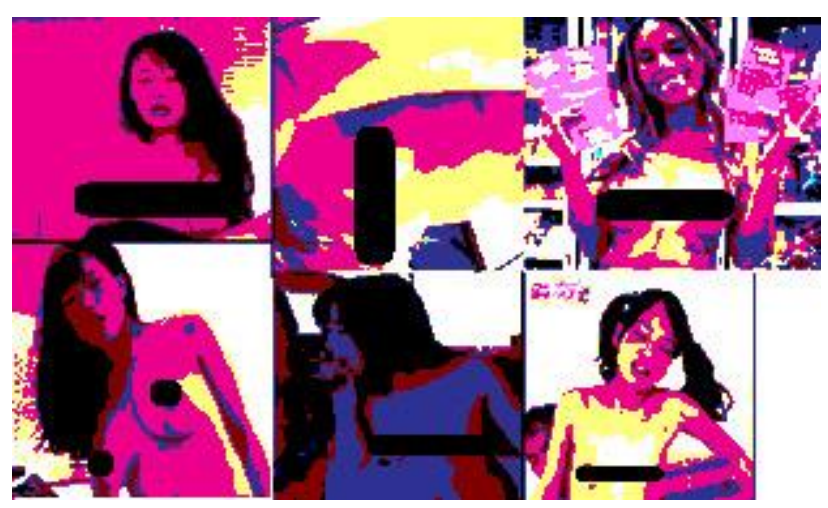

Gambar. 6. Citra Pornografi pada Dataset Dieliminasi

network ini terdiri dari 3 buah Convolutional Layer, diharapkan 2 Convolutional Layer awal mencari fitur yang ada kemudian barulah oleh Convolutional layer ketiga untuk mengambil fitur yang menentukan pornografi. Layer terakhir menggunakan Fully Connected layer sebanyak satu karena activation dari DCNN ini menggunakan sigmoid.

DCNN kedua yang dicoba dibuat dengan menggunakan Residual Network. Tujuannya untuk memperdalam network akan dapat meningkatkan akurasi. Untuk mengurangi berat dari Model yang dihasilkan dalam DCNN yang dibuat ini ditambahkan penggunaan Depthwise Convolutional dan menggunakan Global Average Pooling sebagai pengganti Flatten.

\section{Definisi Citra Pornografi}

Pada penelitian ini sebuah citra dianggap citra pornografi jika menunjukkan secara eksplisit bagian intim. Pada penelitian ini paling banyak yang terlihat eksplisit adalah bagian payudara Wanita. Jika hanya terlihat Sebagian atau tidak secara frontal maka tidak dianggap sebuah citra pornografi.

Pada penelitian ini citra pornografi yang digunakan dalam dataset hanyalah citra dari Wanita saja. Hal ini didasari karena banyaknya penonton yang mencari Wanita saja pada situs Pornografi, yang telah dijelaskan pada bagian pendahuluan. Selain itu citra Wanita yang diambil hanyalah Wanita berkulit putih dan kuning saja yang merupakan mayoritas konten yang dicari dan tersedia. 
TABEL I

HASIl TRAINING MODEL DETEKTOR PORNOGRAFI

\begin{tabular}{lccc}
\hline \hline \multicolumn{1}{c}{ Model } & $\begin{array}{c}\text { Akurasi } \\
\text { Training }\end{array}$ & $\begin{array}{c}\text { Trainable } \\
\text { Parameter }\end{array}$ & $\begin{array}{c}\text { Akurasi } \\
\text { Validasi }\end{array}$ \\
\hline DCNN 1 & $86 \%$ & 135 Juta & - \\
DCNN 2 & $74 \%$ & 41 Juta & - \\
VGG16 & $87 \%$ & 81 Juta & - \\
ResNet50 & $94 \%$ & 23 Juta & $53 \%$ \\
Fine Tuned & $97 \%$ & 28 Juta & $70 \%$ \\
VGG16 & & & \\
Fine Tuned & $98 \%$ & 59 Juta & $78 \%$ \\
EfficientNetB6 & & & \\
Fine Tuned & $98 \%$ & 11.5 Juta & $77 \%$ \\
EfficientNetB3 & & & \\
\hline
\end{tabular}

TABEL II

TRAINING TIME MODEL DETEKTOR PORNOGRAFI

\begin{tabular}{ccc}
\hline \hline MODEL & $\begin{array}{c}\text { Training } \\
\text { Time/Epoch }\end{array}$ & $\begin{array}{c}\text { Waktu } \\
\text { Eksekusi }\end{array}$ \\
\hline DCNN 1 & 12.5 Menit & - \\
DCNN 2 & 20 Menit & - \\
VGG16 & 7 Menit & - \\
ResNet50 & 10 Menit & 1 Detik \\
Fine Tuned VGG16 & 20 Detik & 5.16 Detik \\
Fine Tuned EfficientNetB6 & 44 Detik & 1.56 Detik \\
Fine Tuned EfficientNetB3 & 20 Detik & 1.06 Detik \\
\hline
\end{tabular}

\section{PERCOBAAN DAN ANALISA}

\section{A. Dataset}

Dataset standar untuk penelitian citra pornografi tidak ada maka dari itu dataset yang akan digunakan untuk percobaan ini dibuat sendiri. Dataset dibuat dari citra yang diambil dari film-film pornografi dari Jepang (Japanese Adult Video) dan film pornografi barat ditambah dengan beberapa citra yang dikumpulkan dari mesin pencarian (seperti Google dan Duckduckgo). Hasil citra yang memiliki kualitas kurang baik, tidak memperlihatkan salah satu organ intim, ataupun yang tidak terlalu jelas menampilkan organ intim difilter secara manual. Citra pada dataset ini berjumlah lebih dari 5500 citra dengan ukuran 224x224 pixel. Pada citra yang ditampilkan dataset memang disensor, tetapi pada dataset yang sebenarnya citra tidak tersensor.

Pada pembuatan dataset beberapa percobaan telah dilakukan agar dapat memperoleh hasil yang baik. Selain citra yang memiliki kualitas kurang baik dan tidak menampilkan salah satu organ intim beberapa seleksi lain juga dilakukan. Hal yang membedakan antara payudara wanita dan dada pada pria adalah ukurannya selain itu terdapat beberapa perbedaan lain seperti Areola dan puting pada payudara wanita yang memiliki ukuran lebih besar, akan tetapi Areola ini sendiri dapat menjadi salah satu penyebab sistem cerdas yang akan dibuat tidak mampu mendeteksinya sebagai fitur ponografi, hal ini dikarenakan warna aerola berwarna mirip sekali dengan warna kulit.

Pada citra yang masuk dalam dataset juga akan difilter bedasarkan ukuran payudaranya, citra yang masuk ke dalam dataset merupakan citra yang memiliki ukuran tubuh proporsional. Selain itu citra yang hanya menampilkan alat kelamin wanita saja juga tidak akan disertakan dalam dataset. Hal ini dikarenakan alat kelamin wanita tidak dengan jelas ditunjukkan dengan citra tersebut, dan seringkali banyak kasus dimana alat kelamin wanita tidak
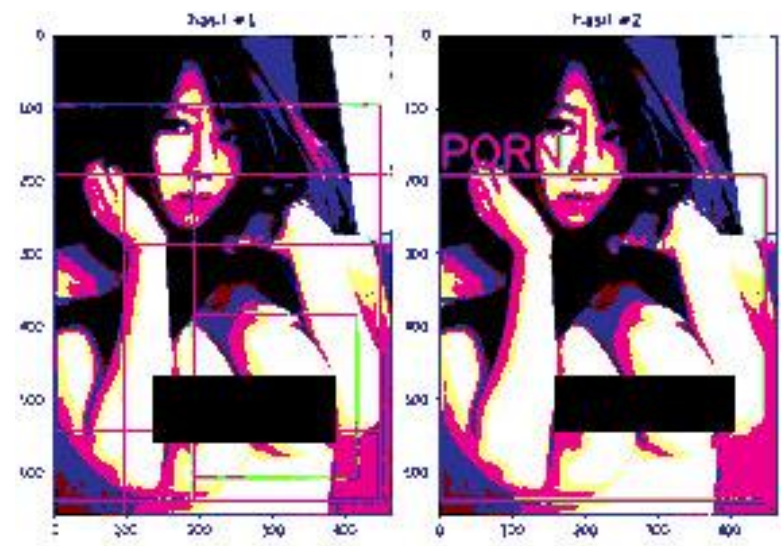

Gambar. 7. Hasil Deteksi dengan EfficientNetB3
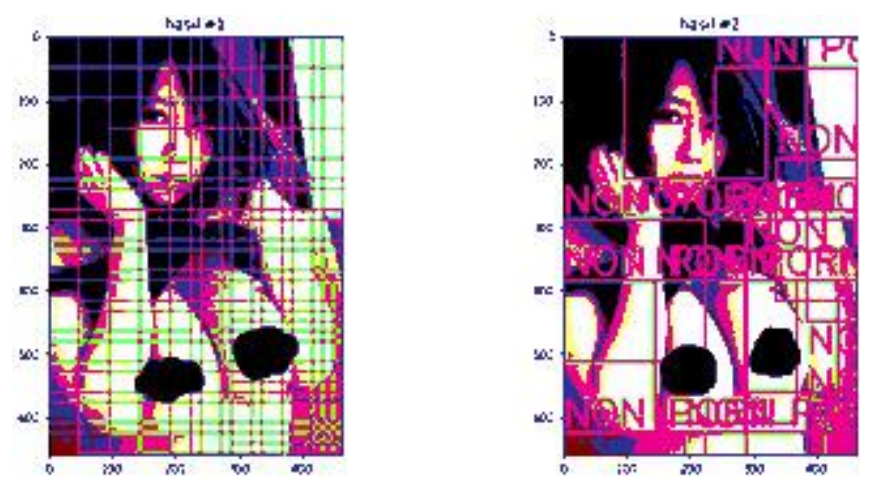

Gambar. 8. Hasil Deteksi dengan EfficientNetB6

memiliki rambut sehingga tidak ada perbedaan dengan citra kulit biasa. Alat kelamin pria juga tidak dijadikan bahan untuk dataset, karena alat kelamin pria jarang ditampilkan secara keseluruhan dan pada citra yang didapat dari film JAV bagian tersebut diberi sensor mosaic. Citra yang tidak masuk ke dalam dataset ini dapat dilihat detailnya pada Gambar 6.

Selain itu dibuat juga dataset lain untuk validasi dengan hasil training. Dataset tersebut adalah dataset validasi yang dibuat dengan cara yang sama dengan dataset untuk training. Dataset ini akan digunakan untuk memvalidasi model yang telah dibuat. Contoh Gambar yang digunakan untuk kedua dataset ini dapat dilihat pada Gambar 5.

\section{B. Hasil Percobaan (Akurasi)}

Hasil training dari model yang telah dibuat dapat dilihat pada Tabel 1. Pada tabel ini juga akan ditampilkan jumlah trainable parameter yang dibutuhkan untuk melatih network ini. Pada model yang dihasilkan tidak semua diuji cobakan dengan menggunakan dataset validasi. Model yang memiliki akurasi diatas $90 \%$ saja yang diujicobakan.

Pada hasil percobaan dapat dilihat model yang diusulkan gagal untuk memperoleh hasil yang diharapkan. Faktor yang mempengaruhi kegagalannya adalah, kompleksitas dari model kurang walaupun jumlah parameternya sangat banyak. Kompleksitas pada hal ini adalah variasi layer pada model dan kedalaman.

Hasil pada penggunaan transfer learning jauh lebih baik karena model-model yang telah ternama lebih mengembangkan pada kompleksitasnya seperti dapat dilihat hasil dari Resnet yang lebih besar dari pada VGG16, dimana notabene ResNet lebih kompleks dari pada VGG. 
Menggunakan Fine Tuning memberikan hasil yang jauh lebih baik lagi, dikarenakan model-model tersebut sebelumnya sudah mampu mendeteksi seperti garis, tepian, dll. Kemudian cukup diberikan sentuhan agar mengenali bagian mana yang merupakan fitur dari citra pornografi. Sedangkan jika ditrain ulang seluruhnya (transfer learning), performa model malah menurun dikarenakan pada proses training ini model belum tentu menemukan fitur-fitur seperti garis dan tepian sebaik sebelumnya.

Fine Tuning menggunakan EfficientNet dicoba dengan menggunakan dua jenis EfficientNet yang berbeda. Percobaan EfficientNet dilakukan dengan menggunakan B6 dan B3. Hasil dari B3 sangatlah baik hanya selisih $1 \%$ akurasi dari data validasi. Hasil object detection yang ditunjukkan pada Gambar 7 merupakan hasil dari B3. Hasil dari EfficientNetB6 mampu menampilkan fitur dari berbagai potongan, sedangkan EfficientNetB3 mampu mendeteksi fitur akan tetapi diambil secara garis besarnya saja. Hasil dari EfficientNetB6 dapat dilihat pada Gambar 8.

\section{Hasil Percobaan (Training Time)}

Training time yang dibutuhkan untuk setiap model juga berbeda-beda, banyaknya parameter serta kompleksitas dari model menentukan durasi yang dibutuhkan untuk mentraining sebuah model. Model yang dibuat dengan menggunakan fine tuned relative memiliki training time yang lebih rendah dikarenakan tidak semua layernya di train. Untuk waktu yang dibutuhkan tiap epochnya dapat dilihat pada Tabel 2.

Waktu yang dibutuhkan untuk sebuah model untuk mendeteksi sebuah citra termasuk citra pornografi atau tidaknya dapat tercermin dari training time. Model usulan juga tidak memenuhi kriteria dari sisi kecepatan karena membutuhkan waktu yang sangat lama untuk menjalankan sebuah epochnya. Sebenarnya model dengan Fine Tuned tidak dapat diukur kecepatannya hanya dengan melihat proses trainingnya, akan tetapi model EfficientNetB3 ataupun EfficientNetB6 tetap lebih cepat dalam menjalankan proses training per epochnya dari pada yang diusulkan.

Selain Melakukan percobaan terhadap Training Time/Epoch percobaan waktu eksekusi juga dilakukan. Waktu ekseskusi ini diuji coba dengan menggunakan 9 citra pornografi maupun bukan. Citra tersebut terdiri dari beberapa macam jenis yaitu citra binatang, citra pornografi dan citra normal yang tidak menampilkan pornografi. Percobaan akan dilakukan dengan menggunakan bantuan google colab. Pada Google Colab GPU yang digunakan adalah NVIDIA Tesla K80 dan dengan Spesifikasi RAM sebesar 12 GB.

Berdasarkan waktu yang dibutuhkan untuk mendeteksi ke 9 citra tersebut ResNet50 memiliki hasil yang paling cepat dibandingkan Model lainnya. Sedangkan EfficientNet berada pada bawahnya dengan selisih yang tidak jauh berbeda, bahkan untuk EfficientNetB6 yang lebih banyak menggunakan parameter selisih waktu yang dibutuhkan tidaklah banyak. Sedangkan VGG16 yang memiliki jumlah parameter lebih kecil memiliki waktu untuk ekseskusi paling lama hingga mencapai 5 detik. Berdasarkan percobaan terhadap waktu dan akurasi pada penelitian ini digunakanlah

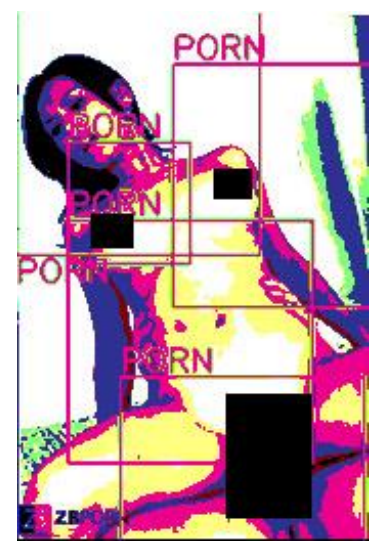

Gambar. 9. Hasil Deteksi Lainnya
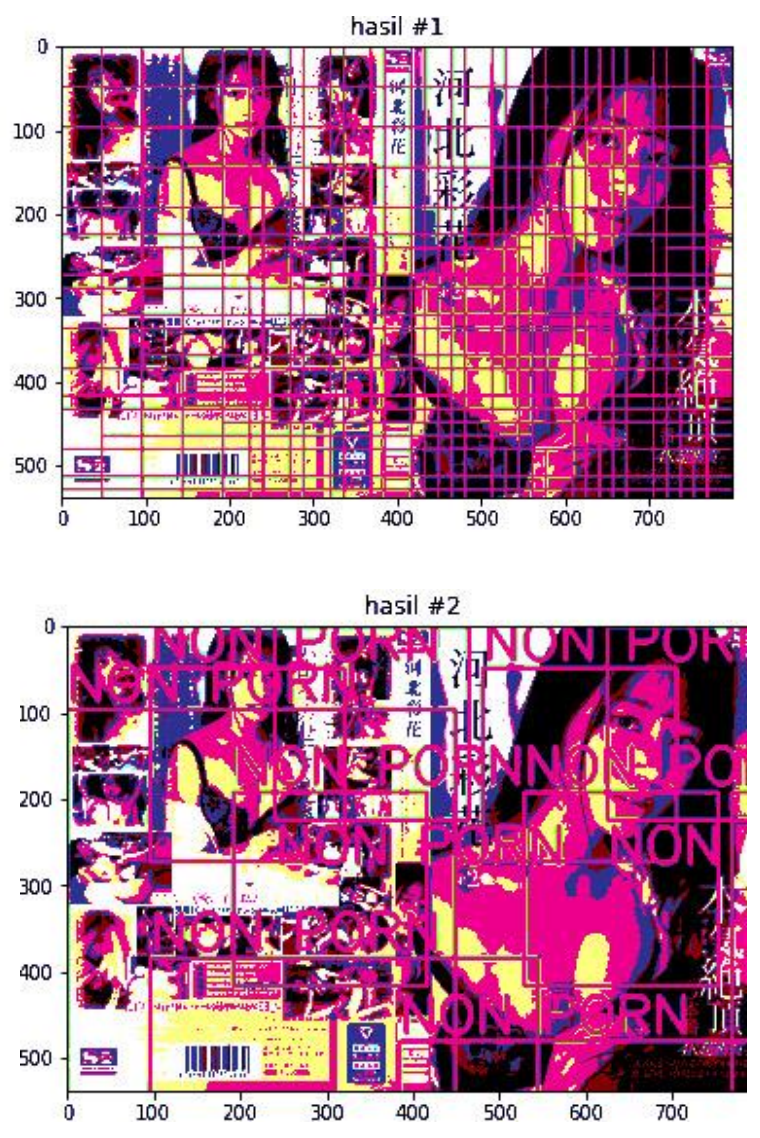

Gambar. 10. Hasil Deteksi Citra Non Pornografi

Model EfficientNet sebagai model yang digunakan untuk mendeteksi citra pornografi.

\section{Object Detection}

Model yang terpilih tidak hanya diperiksa keberhasilannya dengan akurasi yang menggunakan dataset validasi saja. Metode lain yang digunakan untuk memeriksa keberhasilan dari model ini dengan mengubah model sehingga dapat diaplikasikan menjadi Detektor Objek. Untuk membuat model hingga menjadi Detektor Objek dibutuhkan beberapa hal yang yang dilakukan yaitu : Image Pyramid[19], Sliding Windows dan Non Maxima Suppression.

Hasil dari model yang telah diubah menjadi objek Detektor dapat dilihat pada Gambar 6. Pada Gambar 6 areaarea yang menjadi fitur dari sebuah citra termasuk citra pornografi dapat dilihat pada kotak hijau. Gambar sebelah 
kiri merupakan area-area yang menjadi fitur dari citra yang diinputkan sedangkan pada gambar sebelah kanan memperlihatkan area yang dinilai sebagai pornografi. Pada fitur yang ditemukan akan diseleksi lagi untuk dipilih yang memiliki nilai confidence lebih besar. Kotak hijau/fitur yang memiliki nilai confidence lebih rendah akan dieliminasi gambarannya dapat dilihat pada gambar sebelah kanan. Model ini dianggap berhasil karena mampu mendeteksi area payudara sebagai fitur pornografi.

Gambar 9 menampilkan hasil dari deteksi pada citra pornografi lainnya. Pada citra pornografi ini ada dua buah fitur yang ditampilkan (organ intim dari wanita) yaitu payudara dan alat kelamin wanita. Pada hasil percobaan yang ditampilkan model mampu mendeteksi payudara dan alat kelamin wanita. Hasil tersebut ditunjukkan pada kotak hijau yang ditunjukkan. Akan tetapi untuk deteksi alat kelamin wanita tidak semuanya mampu terdeteksi, untuk alat kelamin wanita yang terdapat rambut kemaluannya saja yang dapat terdeteksi, tanpa itu tidak dapat dibedakan antara kulit biasa atau tidak. Kemampuan untuk mendeteksi alat kelamin wanita ini bukanlah menjadi fokus fitur yang dideteksi pada penelitian ini.

Hasil deteksi untuk citra pornografi dapat dilihat pada Gambar 10. Gambar 10 merupakan citra yang mayoritas merupakan citra non pornografi, ketika dilakukan deteksi tidak ditemukan satupun fitur yang merupakan pornografi. Untuk fitur yang tidak merupakan pornografi ditemukan sangat banyak seperti yang dapat dilihat pada Gambar 8 . Akan tetapi sebenarnya pada citra ini terdapat potongan citra pornografi akan tetapi karena dideteksi dengan ukuran $224 \times 224$ pixel bagian dari citra pornografi ini tidak terlihat atau bisa dikatakan bagian pornografi pada citra ini dianggap tidak valid untuk dideteksi.

\section{KESIMPULAN}

Pada penelitian deteksi citra pornografi dilakukan dengan menggunakan Deep Convolutional Neural Network. Untuk setiap citra pornografi yang digunakan telah dipastikan terdapat satu buah fitur pornografi yang tampak secara eksplisit didalamnya (pada penelitian ini adalah payudara wanita). Dengan memastikan hal tersebut memungkinkan pada penelitian ini untuk menggunakan Deep Convolutional Neural Network secara penuh untuk melakukan deteksi pornografi. Bahkan Deep Convolutional Neural Network juga mampu mendeteksi citra pornografi dengan fitur alat kelamin wanita dengan ketentuan tertentu.

Melalui banyak percobaan EfficientNet merupakan model yang paling baik dalam menentukan citra pornografi. Model EfficientNetB6 dianggap paling potensial karena memiliki akurasi yang cukup baik yaitu mencapai $78 \%$ dan memiki waktu untuk mengeksekusi yang cepat(1.56s untuk 9 citra yang berbeda) sedangkan untuk alternatifnya dapat menggunakan model EfficientNetB3 yang memiliki akurasi sedikit lebih rendah dan waktu eksesusi lebih baik. Metode Transfer Learning yang digunakan paling baik menggunakan fine tuning dibandingkan dengan melalukan train ulang untuk seluruh parameter. Hasil yang diperoleh jauh lebih baik dan lebih cepat pada penggunaan Fine Tuning.

Kedepannya penelitian ini akan dikembangkan dan diterapkan menjadi sebuah sistem cerdas untuk mendeteksi citra pornografi yang tampil pada internet. Penambahan Ekstensi untuk mendeteksi citra pornografi yang tampil pada browser akan dicoba sebagai salah satu metode untuk menerapkan penelitian ini dikemudian hari.

\section{DAFTAR PUSTAKA}

[1] Anonymous, "Enough Is Enough: Pornography." https://enough.org/stats_porn_industry.

[2] R. Susanto, "Kementerian Komunikasi dan Informatika." https://kominfo.go.id/content/detail/19631/pornografi-masihmerajai-konten-negatif-internet-indonesia/0/sorotan_media. .

[3] Anonymous, "The 2019 Year in Review - Pornhub Insights," 2019. https://www.pornhub.com/insights/2019-year-in-review.

[4] S. Alamgunawan and Y. Kristian, "Klasifikasi Tekstur Serat Kayu pada Citra Mikroskopik Veneer Memanfaatkan Deep Convolutional Neural Network," J. Intell. Syst. Comput., vol. 2, no. 1, pp. 6-11, 2020.

[5] E. Lim, E. I. Setiawan, and J. Santoso, "Stance Classification Post Kesehatan di Media Sosial Dengan FastText Embedding dan Deep Learning," J. Intell. Syst. Comput., vol. 1, no. 2, pp. 65-73, 2019.

[6] Kominfo, "TrustPositif." https://trustpositif.kominfo.go.id/.

[7] C. X. Ries and R. Lienhart, "A survey on visual adult image recognition," Multimed. Tools Appl., vol. 69, no. 3, pp. 661-688, 2014.

[8] M. J. Jones and J. M. Rehg, "Statistical color models with application to skin detection," Int. J. Comput. Vis., vol. 46, no. 1, pp. 81-96, 2002.

[9] H. A. Nugroho, D. Hardiyanto, and T. B. Adji, "Nipple detection to identify negative content on digital images," in 2016 International Seminar on Intelligent Technology and Its Applications (ISITIA), 2016, pp. 43-48.

[10] Y. Wang, X. Jin, and X. Tan, "Pornographic image recognition by strongly-supervised deep multiple instance learning," in 2016 IEEE International Conference on Image Processing (ICIP), 2016, pp. 4418-4422.

[11] K. Li, J. Xing, B. Li, and W. Hu, "Bootstrapping deep feature hierarchy for pornographic image recognition," in 2016 IEEE International Conference on Image Processing (ICIP), 2016, pp. 4423-4427.

[12] D. Ganguly, M. H. Mofrad, and A. Kovashka, "Detecting sexually provocative images," in 2017 IEEE Winter Conference on Applications of Computer Vision (WACV), 2017, pp. 660-668.

[13] K. Li, J. Xing, B. Li, and W. Hu, "BOOTSTRAPPING DEEP FEATURE HIERARCHY FOR PORNOGRAPHIC IMAGE RECOGNITION National Laboratory of Pattern Recognition CAS Center for Excellence in Brain Science and Intelligence Technology Institute of Automation, Chinese Academy of Sciences , Beijing 100190 , P . R . China."

[14] S. Dewantono and I. Supriana, "Development of a real-time nudity censorship system on images," in 2014 2nd International Conference on Information and Communication Technology (ICoICT), 2014, pp. 30-35.

[15] K. Simonyan and A. Zisserman, "Very deep convolutional networks for large-scale image recognition," arXiv Prepr. arXiv1409.1556, 2014

[16] K. He, X. Zhang, S. Ren, and J. Sun, "Deep residual learning for image recognition," in Proceedings of the IEEE conference on computer vision and pattern recognition, 2016, pp. 770-778.

[17] M. Sandler, A. Howard, M. Zhu, A. Zhmoginov, and L.-C. Chen, "MobileNetV2: Inverted Residuals and Linear Bottlenecks." 2019.

[18] M. Tan and Q. V. Le, "EfficientNet: Rethinking model scaling for convolutional neural networks," 36th Int. Conf. Mach. Learn. ICML 2019, vol. 2019-June, pp. 10691-10700, 2019.

[19] T.-Y. Lin, P. Dollár, R. Girshick, K. He, B. Hariharan, and S. Belongie, "Feature pyramid networks for object detection," in Proceedings of the IEEE conference on computer vision and pattern recognition, 2017, pp. 2117-2125. 